\title{
Withdrawal Period of Enrofloxacin and its Primary Metabolite Ciprofloxacin Residues in Broiler Chicken after Pulse Water Medication
}

\author{
Veerapandian Sureshkumar ${ }^{1 *}$ and Ghadevaru Sarathchandra ${ }^{2}$ \\ ${ }^{1}$ Department of Veterinary Pharmacology and Toxicology, Veterinary College and Research Institute, Tirunelveli, Tamil Nadu \\ Veterinary and Animal Sciences University, INDIA \\ ${ }^{2}$ Dean, Basic Science \& Dean, Madras Veterinary College, Tamil Nadu Veterinary and Animal Sciences University, \\ Chennai, INDIA \\ *Corresponding author: V Sureshkumar; E-mail: drsurpha@gmail.com
}

Received: 07 June, 2021

Revised: 28 July, 2021

Accepted: 14 Aug., 2021

\begin{abstract}
The administration of fluoroquinolone antimicrobials to broiler chicken without an adequate withdrawal time may lead to violative concentrations of residues in edible tissues destined for human consumption. To ensure food safety and human health, withdrawal period of enrofloxacin antimicrobial administration, before slaughter need to be studied based on maximum residue limit values in the target tissues. Hence, the present study has been undertaken to evaluate the withdrawal period and depletion of enrofloxacin and its primary metabolite ciprofloxacin residues in broiler chicken in accordance with MRLs set by various regulatory agencies. Group I (6 birds) was kept as untreated control received non medicated water, and Groups II, III, IV, V and VI each 6 birds were administered with enrofloxacin at recommended therapeutic dose $10 \mathrm{mg}$ per $\mathrm{Kg}$ body weight, through drinking water for five consecutive days from $43^{\text {rd }}$ to $47^{\text {th }}$ day of age. The plasma and edible tissues viz., liver, kidney, muscle (breast \& thigh) and skin were collected and subjected to liquid-liquid extraction followed by enrofloxacin and ciprofloxacin quantification by a validated HPTLC-Fluorescent densitometry assay. Enrofloxacin was well distributed from plasma into tissues and the metabolic conversion of enrofloxacin to ciprofloxacin was observed in all the tissue samples; however the ciprofloxacin concentrations were always lower than that of the parent drug enrofloxacin. Ciprofloxacin was found to be rapidly depleted from the chickens' body compared to that of enrofloxacin. The withdrawal period for enrofloxacin and its metabolite ciprofloxacin residues in broiler chicken was found to be 5 days and 9 days as per European Union and Japan MRLs respectively.
\end{abstract}

\section{HIGHLIGHTS}

(0 Depletion of enrofloxacin from chicken's body was slower than ciprofloxacin.

(- The withdrawal period for enrofloxacin in broiler chicken was 5 days and 9 days as per EU and Japan MRLs respectively.

Keywords: Enrofloxacin, ciprofloxacin, withdrawal period, HPTLC, broiler chicken

Fluoroquinolones antibiotic's usage in the poultry industry have become a matter of concern. It is due to the common use of these compounds to control bacterial infections. It has led to the emergence and dissemination of resistance among microbes viz. Salmonella enterica serovars Enteritidis, Typhimurium, Campylobacter spp. and Escherichia coli (Ponce-Rivas et al., 2012). This has led to decline in therapeutic efficacy of these compounds as therapy for infections in human (Gouvêa et al., 2015). Amongst food of animal origin, antibiotic residues in meat have been a rising trend in the recent years in India. The indiscriminate use of antimicrobials in food-producing animals and poultry may result in the presence of residues in foodstuffs of animal origin (Adamson et al., 2015; Gouvêa et al., 2015).

How to cite this article: Sureshkumar, V. and Sarathchandra, G (2021). Withdrawal Period of Enrofloxacin and its Primary Metabolite Ciprofloxacin Residues in Broiler Chicken after Pulse Water Medication J. Anim. Res., 11(05): 775-782.

Source of Support: None; Conflict of Interest: None 
Enrofloxacin, a fluoroquinolone developed exclusively for veterinary use, has been advocated in poultry in large-scale for treatment of infections like mycoplasma, colibacillosis and pasteurellosis (López-Cadenas et al., 2013; Gouvêa et al., 2015). Following administration in livestock and poultry, enrofloxacin is metabolised in the liver via deethylation into pharmacologically active metabolite ciprofloxacin, which is classified as a "critically important antibiotic" for use in human medicine (BEUC, 2014). On the other hand, ciprofloxacin used to treat diseases of human beings was the most consumed antimicrobial in the world in the first decade of this century. The imprudent use of enrofloxacin in food animals has resulted in the development of resistance in Salmonella and Campylobacter to ciprofloxacin (Bonassa et al., 2017).

In order to regulate the presence of enrofloxacin residues in poultry with the aim of minimizing the risk to human health associated with consumption of their food residues, different countries and regulatory agencies set various maximum residue limits (MRLs) on fluoroquinolone residues and some countries have more rigid regulations than others (Codex Alimentarius International Food Standards, 2018; Moema et al., 2012). The presence of violative levels of residues in foods is illegal and may be subjected to financial penalties in many countries (Vishnuraj et al., 2016). The situation in the developing countries like India is however different, where antimicrobial agents including unapproved fixed dose combination are readily available to farmers over the counter (Laxminarayan and Chaudhary, 2016; McGettigan et al., 2019) and national level surveillance network is not available (Waghamare et al., 2020). Further, information on the levels of fluoroquinolone residues in Indian poultry meat scenario is scarce.

The presence of antibiotic residues in animal tissues is due to the negligence of withdrawal time and inadequate period of time given for the drug to be eliminated from food animals (Monica et al., 2020). In order to ensure food safety and to protect human health, withdrawal period of enrofloxacin antimicrobial administration, before slaughter need to be studied based on MRL values in the target tissues (i.e. muscle, skin, liver and kidney) of food animals.

In this context, to ensure the prudent and responsible use of enrofloxacin in veterinary medicine, the present study has been undertaken to evaluate the withdrawal period and depletion of enrofloxacin and its primary metabolite ciprofloxacin residues in plasma and edible tissues of broiler chicken under controlled experimental condition in accordance with MRLs set by various regulatory agencies.

\section{MATERIALS AND METHODS}

\section{Location of work}

The present study was conducted at Pharmacovigilance Laboratory for Animal Feed and Food Safety, Directorate of Centre for Animal Health Studies, Tamil Nadu Veterinary and Animal Sciences University, Chennai as a part of Ph.D. research work of the first author under the guidance of the second author during the year from 2009 to 2013. Necessary approval was obtained from Institutional animal ethics committee (IAEC/MVC/DPV08012/2009), Madras Veterinary College, TANUVAS for conducting the experiment.

\section{Experimental birds and enrofloxacin dosing protocol}

Day old broiler chicks (Broiler strain $\mathrm{B}_{1}$ ) of thirty-six numbers obtained from Institute of Poultry Production and Management, TANUVAS, Chennai were randomly allocated in to six groups of six birds each on very first day of age. Birds received their freshly prepared daily medication during a 4 hour period in the morning, and their water was antibiotic free for the remaining 20 hour of each day. The pulse water medication was followed as per the methods described by Charleston et al., 1998. Birds of group I were placed as control, received plain non medicated water and the birds from groups II, III, IV, V and VI received enrofloxacin at recommended therapeutic dose i.e., $10 \mathrm{mg}$ per $\mathrm{Kg}$ body weight, through drinking water, for five consecutive days from $43^{\text {rd }}$ to $47^{\text {th }}$ day of age as reported by us earlier (Sureshkumar et al., 2012).

\section{Sampling protocol}

Blood samples were collected from wing vein into sterile heparinised vials from control and treatment groups (6 birds each) at different time points as follows; at 24 hours interval during the dosing period after administration of the first dose ( $44^{\text {th }}$ to $47^{\text {th }}$ day of age) and during the withdrawal period at 48 hours interval on day 1, 3, 5, 7 
and 9 post treatment. Blood samples collected in the heparinised tubes were centrifuged at $5000 \mathrm{rpm}$ for 10 minutes at room temperature, and the separated plasma was stored at $-20^{\circ} \mathrm{C}$ until analysis. After cessation of the last dose of enrofloxacin, birds from treatment groups II, III, IV, V and VI were sacrificed ethically on 1, 3, 5, 7 and 9 days post treatment respectively. Control birds were sacrificed at the end of the experiment. Tissue samples viz., liver, kidney, muscle (breast and thigh) and skin were collected and stored at $-20^{\circ} \mathrm{C}$ until analysis.

\section{High performance thin layer chromatography analysis}

The plasma and tissue samples were subjected to liquid-liquid extraction followed by enrofloxacin and ciprofloxacin quantification by a validated HPTLCFluorescent densitometry assay as explained by us earlier (Sureshkumar and Sarathchandra, 2018). The HPTLC system (Camag, Switzerland) comprising Linomat-5 applicator and a TLC scanner-3 densitometer equipped with WinCATs 1.4.4 version software was used in the present study. The HPTLC calibration curve for enrofloxacin and ciprofloxacin were presented in Figs. 1 and 2 respectively.

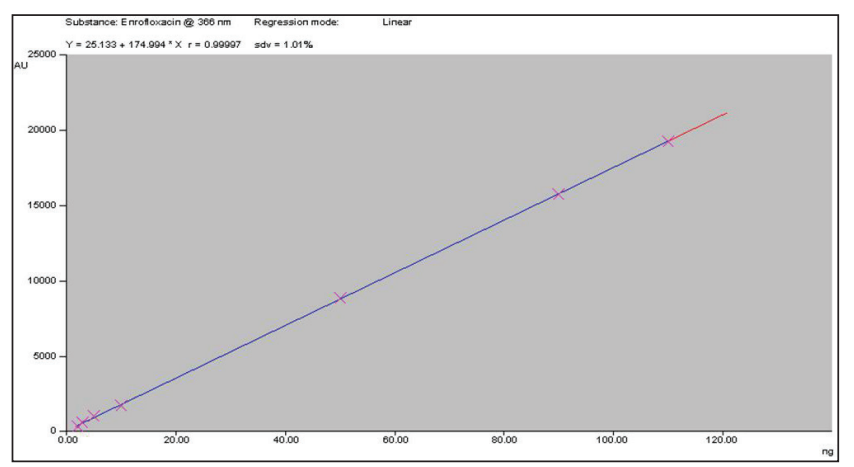

Fig. 1: HPTLC calibration curve for enrofloxacin

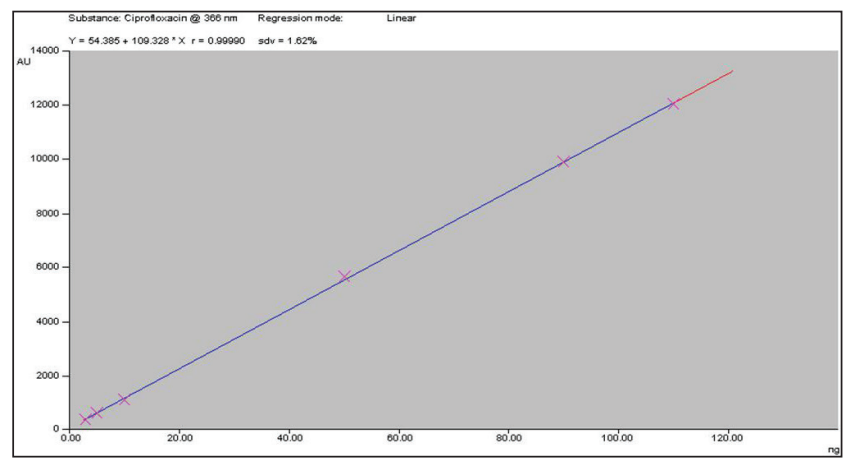

Fig. 2: HPTLC calibration curve for ciprofloxacin
The HPTLC typical chromatogram of enrofloxacin and ciprofloxacin is presented in Fig. 3.

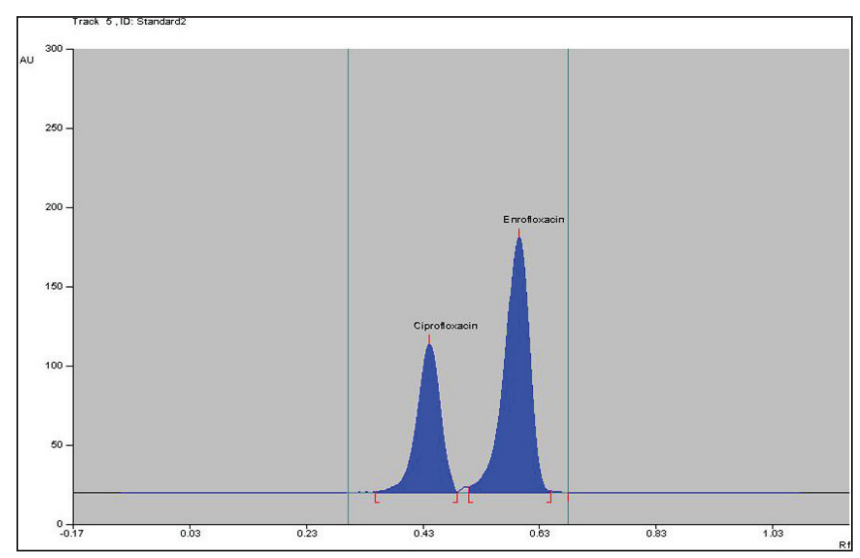

Fig. 3: HPTLC typical chromatogram of enrofloxacin and ciprofloxacin standard

\section{RESULTS AND DISCUSSION}

\section{Enrofloxacin and its metabolite ciprofloxacin residues in plasma}

Enrofloxacin and its metabolite ciprofloxacin residues in plasma of broiler chicken during treatment and post treatment period are shown in Table 1. Enrofloxacin could be detected in ascending concentration in plasma, 24 hours after $1^{\text {st }}$ dose during treatment, attaining highest concentration $(351.82 \pm 6.23 \mu \mathrm{g} / \mathrm{L})$ after $4^{\text {th }}$ dose. High concentrations of the enrofloxacin in plasma, 24 hour after the beginning of the dosing are consequence of rapid absorption from chicken intestines (Prescott et al., 2000). Peak serum concentration occurs within 72 hours (Anadon et al., 1990). Reyes-Herrera et al. (2011) reported that the plasma concentration of enrofloxacin peaked $(379 \pm 92 \mathrm{ng} /$ $\mathrm{mL}$ and $705 \pm 59 \mathrm{ng} / \mathrm{mL}$ ) at day 3 of the dosing period in the low dose group ( $25 \mu \mathrm{g} / \mathrm{mL}$ for 3 days $)$ and the high dose group ( $50 \mu \mathrm{g} / \mathrm{mL}$ for 7 days) respectively. However, during the withdrawal period, enrofloxacin concentration started to decline after day 1 post treatment $(324.42 \pm 45.45 \mu \mathrm{g} / \mathrm{L})$ and sharp decline was noticed on day 3 post treatment $(23.01 \pm 2.64 \mu \mathrm{g} / \mathrm{L})$. Enrofloxacin could not be detected after $5^{\text {th }}$ day post treatment onwards. No enrofloxacin residues could be detected in plasma of the control group studied. While ciprofloxacin, the primary metabolite of enrofloxacin could be detected in plasma after $3^{\text {rd }}$ dose of 
enrofloxacin and attained peak concentration after $4^{\text {th }}$ dose $(38.82 \pm 1.39 \mu \mathrm{g} / \mathrm{L})$. However, during withdrawal period ciprofloxacin could be detected on day 1 post treatment only, it wasn't detectable on day 3 and onward, post treatment.

Table 1: Enrofloxacin and its metabolite ciprofloxacin residues $(\mu \mathrm{g} / \mathrm{L})$ in plasma of broiler chicken

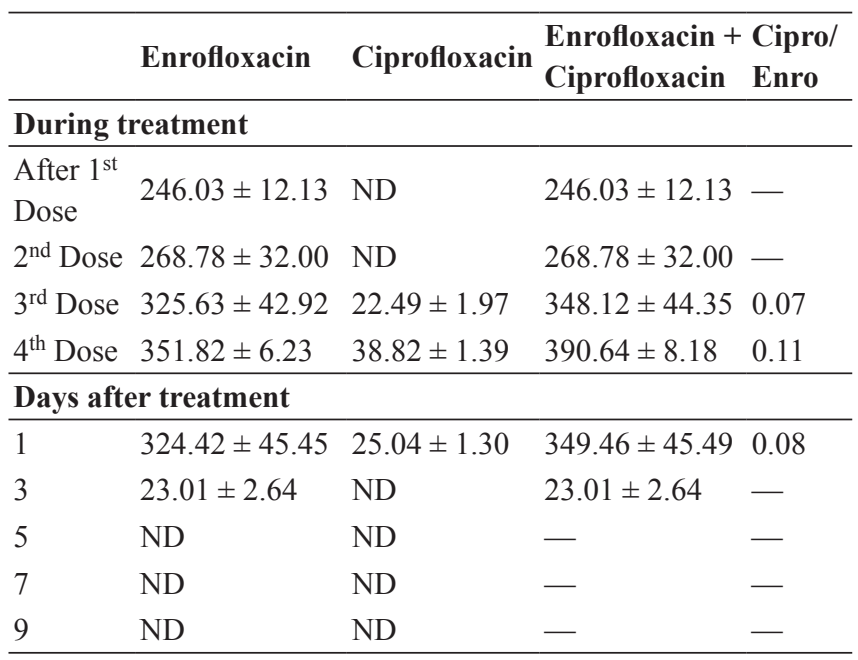

Note: Mean $\pm S E, n=6 . N D-$ Not detected. Limit of detection -2 $n g / b a n d$ for enrofloxacin and $3 \mathrm{ng} / \mathrm{band}$ for ciprofloxacin. Limit of quantification - $5 \mathrm{ng} / \mathrm{band}$ for both the compounds.

\section{Enrofloxacin and its metabolite ciprofloxacin residues} in edible tissues

The residue profile of enrofloxacin and its metabolite ciprofloxacin in edible tissues viz., liver, kidney, skin and muscle (breast \& thigh) samples are furnished in Table 2 and 3. In liver and kidney the concentrations of both enrofloxacin and its metabolite ciprofloxacin exceeded the plasma concentrations on day 1 post treatment group. In breast muscle, the enrofloxacin concentration was near equal to that of plasma, but in thigh muscle and skin it was below the level of plasma concentration on day 1 post treatment group. However, enrofloxacin concentration exceeded the plasma concentration on day 3 post treatment group in all the tissues studied. Liver and kidney showed highest Enro $_{\text {Tissue }} /$ Enro $_{\text {Plasma }}$ and $\mathrm{Cipro}_{\text {Tissue }} / \mathrm{Cipro}_{\text {Plasma }}$ ratio (Table 2), which is attributed to its high tissue: blood concentration ratio (Garcia Ovando et al., 1999). These findings are in line with Papich and Riviere (2009) who also reported in tissues, such as liver and kidney with fluoroquinolone concentrations several fold higher than corresponding plasma concentrations.

Enrofloxacin is well distributed from plasma into tissues (Intorre et al., 1997), which is very well reflected in the results with maximum tissue concentration on day 1 post treatment in liver, kidney, breast muscle, skin and thigh muscle (Table 2 and 3 ).

Enrofloxacin concentration was higher in the liver than in breast and thigh muscles at all the time points examined in the present study. Its concentration was 1.52-1.80 and 1.982.71 times higher in the liver than breast and thigh muscles on the first- and third-day post treatment respectively. This correlation slowly declined on day 5 post treatment to 1.41-2.15 times, on day 7 post treatment, 1.16-2.07 times and on day 9 post treatment, 0.57-0.91 times accordingly. The results obtained were in accordance to the earlier findings regarding the distribution of enrofloxacin in the liver and muscle as reported by Petrovic et al. (2006). In addition, Petrovic et al. (2006) found the concentration of enrofloxacin, 3.78 times higher in liver as compared to muscles, 24 hour after the beginning of treatment. This correlation gradually declined down on day 1 post treatment to 2.07 times and on day 4 post treatment to 1.94 times. This reduction ceased after this period and correlation was equalized at 1.82 times. These results point to extensive metabolism of enrofloxacin in the liver during treatment and led to gradual elimination from the chicken's body. Enrofloxacin is metabolised in the liver and transformed into the main metabolite i.e., ciprofloxacin and some minor metabolites such as: oxociprofloxacin, enrofloxacin amide, dioxociprofloxacin, desethylene ciprofloxacin, destethylene enrofloxacin, N-formyl ciprofloxacin, oxoenrofloxacin and hydroxy oxoenrofloxacin (Prescott et al., 2000).

The level of enrofloxacin transformation to ciprofloxacin is not so high in the present study. The ciprofloxacin concentrations were always lower than that of the parent drug enrofloxacin. In liver and kidney, the ciprofloxacin: enrofloxacin ratio ranged from 0.20 to 0.70 and 0.28 to 0.62 respectively. Whereas, in skin, breast and thigh muscle the ciprofloxacin: enrofloxacin ratio was found to be from 0.04 to 0.06 . With the exception of excretory organs liver (20-70\%) and kidney (28-62\%), tissue (skin, breast and thigh muscle) ciprofloxacin never exceeded the 
Table 2: Enrofloxacin and its metabolite ciprofloxacin residues $(\mu \mathrm{g} / \mathrm{Kg})$ in liver, kidney and skin of broiler chicken

\begin{tabular}{|c|c|c|c|c|c|c|}
\hline $\begin{array}{l}\text { Days after } \\
\text { treatment }\end{array}$ & Enrofloxacin & Ciprofloxacin & $\begin{array}{l}\text { Enrofloxacin + } \\
\text { Ciprofloxacin }\end{array}$ & $\begin{array}{l}\text { Cipro/ } \\
\text { Enro } \\
\end{array}$ & $\begin{array}{l}\text { Enro }_{\text {Tissue }} / \\
\text { Enro }_{\text {Plasma }}\end{array}$ & $\begin{array}{l}\text { Cipro }_{\text {Tissue }} \\
\text { Cipro }_{\text {Plasma }}\end{array}$ \\
\hline \multicolumn{7}{|l|}{ Liver } \\
\hline 1 & $489.59 \pm 23.29$ & $341.34 \pm 15.10$ & $830.93 \pm 25.31$ & 0.70 & 1.51 & 13.63 \\
\hline 3 & $292.17 \pm 11.74$ & $79.19 \pm 9.70$ & $371.36 \pm 10.43$ & 0.27 & 12.70 & - \\
\hline 5 & $127.05 \pm 2.33$ & $24.92 \pm 1.31$ & $151.97 \pm 3.33$ & 0.20 & - & - \\
\hline 7 & $33.96 \pm 0.91$ & $6.86 \pm 0.41$ & $40.82 \pm 1.13$ & 0.20 & - & - \\
\hline 9 & $5.01 \pm 0.23$ & ND & $5.01 \pm 0.23$ & - & - & - \\
\hline \multicolumn{7}{|l|}{ Kidney } \\
\hline 1 & $367.88 \pm 21.85$ & $227.49 \pm 8.38$ & $595.37 \pm 22.51$ & 0.62 & 1.13 & 9.09 \\
\hline 3 & $273.62 \pm 10.41$ & $81.99 \pm 1.50$ & $355.61 \pm 9.59$ & 0.30 & 11.89 & - \\
\hline 5 & $115.78 \pm 1.47$ & $32.97 \pm 0.24$ & $148.75 \pm 1.71$ & 0.28 & - & - \\
\hline 7 & $25.54 \pm 1.77$ & $7.86 \pm 0.60$ & $33.40 \pm 2.11$ & 0.31 & - & - \\
\hline 9 & $5.98 \pm 0.20$ & ND & $5.98 \pm 0.20$ & - & - & - \\
\hline \multicolumn{7}{|l|}{ Skin } \\
\hline 1 & $311.89 \pm 7.24$ & $14.68 \pm 1.30$ & $326.57 \pm 8.10$ & 0.05 & 0.96 & 0.59 \\
\hline 3 & $116.91 \pm 3.14$ & $7.09 \pm 0.45$ & $124.00 \pm 3.13$ & 0.06 & 5.08 & - \\
\hline 5 & $63.77 \pm 0.69$ & ND & $63.77 \pm 0.69$ & - & - & - \\
\hline 7 & $12.86 \pm 0.34$ & ND & $12.86 \pm 0.34$ & - & - & - \\
\hline 9 & $5.61 \pm 0.30$ & ND & $5.61 \pm 0.30$ & - & - & - \\
\hline
\end{tabular}

Note: Mean \pm SE, $n=6$. ND - Not detected. Limit of detection $-2 \mathrm{ng} / \mathrm{band}$ for enrofloxacin and $3 \mathrm{ng} / \mathrm{band}$ for ciprofloxacin. Limit of quantification - $5 \mathrm{ng} / \mathrm{band}$ for both the compounds.

Table 3: Enrofloxacin and its metabolite ciprofloxacin residues $(\mu \mathrm{g} / \mathrm{Kg})$ in muscles of broiler chicken

\begin{tabular}{|c|c|c|c|c|c|c|}
\hline $\begin{array}{l}\text { Days after } \\
\text { treatment }\end{array}$ & Enrofloxacin & Ciprofloxacin & $\begin{array}{l}\text { Enrofloxacin + } \\
\text { Ciprofloxacin }\end{array}$ & $\begin{array}{l}\text { Cipro/ } \\
\text { Enro } \\
\end{array}$ & $\begin{array}{l}\text { Enro }_{\text {Tissue }} / \\
\text { Enro }_{\text {Plasma }}\end{array}$ & $\begin{array}{l}\text { Cipro }_{\text {Tissue }} \\
\text { Cipro }_{\text {Plasma }}\end{array}$ \\
\hline \multicolumn{7}{|c|}{ Muscle-Breast } \\
\hline 1 & $323.03 \pm 6.12$ & $14.20 \pm 1.87$ & $337.23 \pm 4.97$ & 0.04 & 1.00 & 0.57 \\
\hline 3 & $147.46 \pm 1.86$ & $7.48 \pm 0.54$ & $154.94 \pm 1.78$ & 0.05 & 6.41 & - \\
\hline 5 & $90.37 \pm 2.90$ & ND & $90.37 \pm 2.90$ & - & - & - \\
\hline 7 & $29.37 \pm 0.74$ & ND & $29.37 \pm 0.74$ & - & - & - \\
\hline 9 & $8.85 \pm 0.18$ & ND & $8.85 \pm 0.18$ & - & - & - \\
\hline \multicolumn{7}{|c|}{ Muscle-Thigh } \\
\hline 1 & $272.63 \pm 6.65$ & $13.49 \pm 2.05$ & $286.12 \pm 4.95$ & 0.05 & 0.84 & 0.54 \\
\hline 3 & $107.72 \pm 2.30$ & $5.87 \pm 0.49$ & $113.59 \pm 1.94$ & 0.05 & 4.68 & \\
\hline 5 & $58.99 \pm 2.09$ & ND & $58.99 \pm 2.09$ & - & - & - \\
\hline 7 & $16.43 \pm 0.48$ & ND & $16.43 \pm 0.48$ & - & - & - \\
\hline 9 & $5.50 \pm 0.08$ & ND & $5.50 \pm 0.08$ & - & - & - \\
\hline
\end{tabular}

Note: Mean \pm SE, $n=6$. ND - Not detected. Limit of detection $-2 \mathrm{ng} / \mathrm{band}$ for enrofloxacin and $3 \mathrm{ng} / \mathrm{band}$ for ciprofloxacin. Limit of quantification - $5 \mathrm{ng} / \mathrm{band}$ for both the compounds.

4-6\% of the parent drug concentrations in the present study. These findings are very well substantiated by Knoll et al. (1999), who reported that ciprofloxacin concentrations in chicken's liver, kidney and tissues were about 38\%, 11\% and $4 \%$ of the enrofloxacin values respectively.
On the contrary, Anadon et al. (1995) reported that ciprofloxacin level is always similar or greater than enrofloxacin level. But, observations of the present study are in absolute correspondence with the results obtained by Schneider (2001) and Petrovic et al. (2006). In fact, 
Schneider (2001) treated chickens with enrofloxacin 11 $\mathrm{mg} / \mathrm{Kg} /$ day for seven days and found 2-10 times lower levels of ciprofloxacin in the meat and liver. Petrovic et al. (2006) studied the enrofloxacin residues in muscle and liver after oral administration of enrofloxacin $\left(10 \mathrm{mg} \mathrm{Kg}^{-1} /\right.$ day) to chickens and found that most of the residue in the liver and muscles at the end of treatment was enrofloxacin. Besides, the present study results are comparable to the data published by EMEA report (1998): in chickens, 61 to $66 \%, 51 \%, 53$ to $62 \%$ and $85 \%$ of the total residues present in kidney, liver, fat and muscle respectively were present as enrofloxacin.

The metabolic conversion of enrofloxacin to ciprofloxacin was observed in all the tissue samples obtained from enrofloxacin treated chickens. The descending order of tissue levels of enrofloxacin and its metabolite ciprofloxacin residues as found in broiler tissues wise is as follows; liver $>$ kidney $>$ breast muscle $>$ skin $>$ thigh muscle. Enrofloxacin was efficiently distributed to most tissues, as evidenced by its detection in all the tissues, at all the time points studied during the withdrawal period. This is attributed owing to its lipophilicity and low protein binding capacity (Papich and Riviere, 2009).

In contrast, ciprofloxacin could be detected in liver and kidney until day 7 post treatment and in muscle (breast and thigh) and skin until day 3 post treatment. Ciprofloxacin has a partition coefficient that is approximately 100fold less than that of enrofloxacin (Papich and Riviere, 2009). Garcia Ovando et al. (1999) reported that the total body clearance $\left(\mathrm{Cl}_{\mathrm{B}}\right)$ for ciprofloxacin $(15.45 \pm 1.63$ $\mathrm{mL} / \mathrm{min} / \mathrm{Kg}$ ) was five times higher than that obtained for enrofloxacin $(3.30 \pm 0.14 \mathrm{~mL} / \mathrm{min} / \mathrm{kg})$. This indicated the slower elimination of enrofloxacin in the body and the ciprofloxacin remains in the body for lesser time than enrofloxacin. Higher clearance of ciprofloxacin indicates the reduced possibility of finding residues of the antimicrobial in broiler chickens a few days after treatment and the necessity of a shorter withdrawal time for ciprofloxacin. In addition, Anadon et al. (2001) also found that ciprofloxacin was more rapidly eliminated from liver and skin plus fat.

\section{Withdrawal period}

According to EU, MRLs (Commission Regulation (EU), 2010) the withdrawal period for enrofloxacin and its metabolite ciprofloxacin in liver, kidney, muscle (breast and thigh) and skin was found to be 5 days. Whereas, according to Japan MRLs (Ministry of Health and Welfare, Japan, 2005) the withdrawal period was 9 days (Table 4). Even though the present study found greater residue concentrations in breast versus thigh muscle tissues, it did not influence the withdrawal period. These findings are in close agreement with Petrovic et al. (2006), who reported that broiler chicken, administered with enrofloxacin $10 \mathrm{mg}$ $\mathrm{Kg}^{-1} /$ day, in drinking water, for five consecutive days followed by withdrawal period of four days causes the drug concentration to decline, to an acceptable level in the broiler meat and liver prior to slaughter (below EU MRL). While, San Martin et al. (2010) observed that based on the European Community and Chile MRLs of $100 \mu \mathrm{g} \mathrm{Kg}$ (muscle) and $200 \mu \mathrm{g} / \mathrm{Kg}$ (liver), the withdrawal times did not exceed 5 days. When Japan MRL was considered $(10 \mu \mathrm{gKg}$,$) , the withdrawal times increased up to 8$ days in broiler chicken, orally administrated with enrofloxacin at the dose rate of $10 \mathrm{mg} \mathrm{Kg}^{-1}$, once-a-day during five consecutive days.

According to San Martin et al. (2007) and Chattha et al. (2008), the former authors reported a withdrawal time of 6 days based on EU MRLs and 9 days based on Japan MRLs in laying hens treated intramuscularly with $5 \%$ enrofloxacin at $10 \mathrm{mg} / \mathrm{kg}$ body weight over 3 days. While, latter authors observed that enrofloxacin residues were washed out in 9 days whilst its major metabolite ciprofloxacin was washed out in 8 days in chicken meat and concluded that poultry food should not be marketed before 6-9 days after enrofloxacin medication. The difference in the withdrawal periods perceived from that of other authors report could be attributed to formulation of enrofloxacin used in the present study. Variations in drugs formulations, particularly if different vehicles are used, renders the absorption kinetics of the used antibiotics differ (Sumano and Ocampo, 1995). These changes in the pharmacokinetics variables may modify withdrawals period, and have impact on the presence of drug residues in food (Sumano et al., 2001). In this regard, Kukanich et al. (2005) pointed out that the formulation can have profound effects on the pharmacokinetic and depletion of the drug.

Indiscriminate and irrational use of antibiotics in poultry without following withdrawal period may result in unexpected residues in meat. Occurrence of antibiotics in 
poultry tissue and feed samples could pose risk to human and animal health if they are transferred to human via food chain. Therefore, the poultry farming and processing systems should be kept under continuous monitoring in order to prevent the occurrence of residue in meat and meat products (Waghamare et al., 2020).

Table 4: Withdrawal periods for enrofloxacin and its primary metabolite ciprofloxacin in various edible tissues of broiler chicken according to MRLs

\begin{tabular}{lll}
\hline \multirow{2}{*}{ Edible tissues } & \multicolumn{2}{c}{ Withdrawal period (days) } \\
\cline { 2 - 3 } & EU MRLs & Japan MRLs \\
\hline Liver & 5 & 9 \\
Kidney & 5 & 9 \\
Muscle (Breast and & & \\
Thigh) & 5 & 9 \\
Skin & 5 & 9 \\
\hline
\end{tabular}

\section{CONCLUSION}

Enrofloxacin gets efficiently distributed from plasma into most of the tissues. The metabolic conversion of enrofloxacin to ciprofloxacin was observed in all the tissue samples, However, the level of its transformation to ciprofloxacin is not high enough in the present study. The ciprofloxacin concentrations were always lower than that of the parent drug enrofloxacin. Ciprofloxacin was found to be rapidly depleted from the chickens' body compared to that of enrofloxacin. The withdrawal period for enrofloxacin and its metabolite ciprofloxacin in broiler chicken was found to be 5 days and 9 days as per EU and Japan MRLs respectively.

\section{ACKNOWLEDGEMENTS}

The Authors are highly grateful to Drugs and Pharmaceutical Research Programme, Department of Science and Technology, Government of India, New Delhi, for the financial support as part of the DST scheme entitled "A National Facility for Pharmacovigilance on Drug Residue and other Toxic Xenobiotics including Genetically Manipulated Organisms in Veterinary Products" at Pharmacovigilance Laboratory for Animal Feed and Food Safety, Directorate of Centre for Animal Health Studies, Tamil Nadu Veterinary and Animal Sciences University, Chennai.

\section{REFERENCES}

Adamson, D.H., Krikstopaityte, V. and Coote, P.J. 2015. Enhanced efficacy of putative efflux pump inhibitor/antibiotic combination treatments versus MDR strains of Pseudomonas aeruginosa in a Galleria mellonella in vivo infection model. J. Antimicrob. Chemother, 70: 2271-2278.

Anadon, A., Martinez-Larranaga, M.R., Diaz, M.J., Bringas, P., Martinez, M.A., Fernandez-Cruz, M.L., Fernandez, M.C. and Fernandez, R. 1995. Pharmacokinetics and residues of enrofloxacin in chickens. Am. J. Vet. Res., 56: 501-506.

Anadon, A., Martinez-Larranaga, M.R., Diaz, M.J., Velez, C. and Bringas, P. 1990. Pharmacokinetics and residue studies of quinolone compounds and olaquindox in poultry. Ann. Rech. Vet., 1: 137S-144S.

Anadon, A., Martinez-Larranaga, M.R., Iturbe, J., Martinez, M.A., Diaz, M.J., Frejo, M.T. and Martinez, M. 2001. Pharmacokinetics and residues of ciprofloxacin and its metabolites in broiler chickens. Res. Vet. Sci., 71: 101-109.

BEUC, 2014. Bureau Europeen des Union des Consommateurs. European consumer organization. Antibiotic use in livestock: Time to act. BEUC-X-2014-043 of 11 $1^{\text {th }}$ June 2014, 0126.

Bonassa, K.P.D., Miragliotta, M.Y., Simas, R.C., Monteiro, D.A., Eberlin, M.N., Anadón, A. and Reyes, F.G.R. 2017. Tissue depletion study of enrofloxacin and its metabolite ciprofloxacin in broiler chickens after oral administration of a new veterinary pharmaceutical formulation containing enrofloxacin. Food Chem. Toxicol., 105: 8-13.

Charleston, B., Gate, J.J., Aitken, I.A., Stephan, B. and Froyman, R. 1998. Comparison of the efficacies of three fluoroquinolone antimicrobial agents, given as continuous or pulsed-water medication, against Escherichia coli infection in chickens. Antimicrob. Agents Chemother., 42: 83-87.

Chattha, F.A., Nawaz, R. and Munawar, M.A. 2008. The study of withdrawal period of enrofloxacin and its residues in poultry foods. J. Chem. Soc. Pak., 30: 155-157.

Codex Alimentarius International Food Standards. 2018. Maximum residue limits (MRLs) and risk management recommendations (RMRs) for residues of veterinary drugs in foods. CX/MRL 2: 1-46.

Commission Regulation (EU). 2010. Commission regulation (EU) No 37/2010 of 22 December 2009 on pharmacologically active substances and their classification regarding maximum residue limits in foodstuffs of animal origin. Official J. Europ. Union, L15, 53: 1-72.

EMEA. 1998. Committee for veterinary medicinal products. Enrofloxacin. Summary report (2), EMEA/MRL/388/98FINAL, pp. 1-6.

Garcia Ovando, H., Gorla, N., Luders, C., Poloni, G., Errecalde, C., Prieto, G. and Puelles, I. 1999. Comparative 
pharmacokinetics of enrofloxacin and ciprofloxacin in chickens. J. Vet. Pharmacol. Therap., 22: 209-212.

Gouvêa, R., Santos, FF dos., Aquino, MHC de., Pereira, VL de A. 2015. Fluoroquinolones in industrial poultry production, bacterial resistance and food residues: a review. Braz. J. Poult. Sci., 17: 1-10.

Intorre, I., Mengozzi, G., Bertini, S., Bagliacca, M., Luchetti, E. and Soldani, G. 1997. The plasma kinetics and tissue distribution of enrofloxacin and its metabolite ciprofloxacin in the muscovy duck. Vet. Res. Comm., 21: 127-136.

Knoll, U., Glunder, G. and Kietzmann, M. 1999. Comparative study of the plasma pharmacokinetics and tissue concentrations of danofloxacin and enrofloxacin in broiler chickens. J. Vet. Pharmacol. Therap., 22: 239-246.

Kukanich, B., Gehring, R., Webb, A., Craigmill, A. and Riviere, J. 2005. Effect of formulation and route of administration on tissue residues and withdrawal times. J. Am. Vet. Med. Assoc., 227: 1574-1577.

Laxminarayan, R. and R.R. Chaudhury. 2016. Antibiotic resistance in India: Drivers and opportunities for action. PLoS Medicine, 13: e1001974.

López-Cadenas, C., Sierra-Vega, M., García-Vieitez, J.J., DiezLiébana, M.J., Sahagún-Prieto, A. and Fernández-Martínez, N. 2013. Enrofloxacin: pharmacokinetics and metabolism in domestic animal species. Curr. Drug Metab., 14: 1042-1058.

McGettigan, P., Roderick, P., Kadam, A. and Pollock, A. 2019. Threats to global antimicrobial resistance control: Centrally approved and unapproved antibiotic formulations sold in India. Br. J. Clin. Pharmacol., 85: 59-70.

Ministry of Health and Welfare, Japan. 2005. Specifications and standards for food, food additives. Notification no. 499. Ministry of Health and Welfare, Tokyo.

Moema, D., Nindi, M. and Dube, S. 2012. Development of a dispersive liquid-liquid microextraction method for the determination of fluoroquinolones in chicken liver by high performance liquid chromatography. Anal. Chim. Acta, 730: 80-86.

Monica, B., Sarathchandra, G. and Preetha. S. P. 2020. Evaluation of Escherichia Coli as a microbial tool in residue monitoring of enrofloxacin in milk. Int. J. Curr. Microbiol. App. Sci., 9: 2483-2490.

Papich, M.G. and Riviere, J.E. 2009. Fluoroquinolone antibacterial drugs. In: Veterinary Pharmacology and Therapeutics. Riviere, J.E. and Papich, M.G. $9^{\text {th }}$ Edn., Wiley-Blackwell, Iowa State University Press, USA, pp. 983-1011.

Petrovic, J., Baltic, M. Cupic, V., Stefanovic, S. and Dragica, S. 2006. Residues of enrofloxacin and its main metabolite ciprofloxacin in broiler chickens. Acta Vet. (Beograd), 56: 497-506.
Ponce-Rivas, E., Muñoz-Márquez, M.E. and Khanc, A.A. 2012. Identification and molecular characterization of Class 1 integrons in multiresistant Escherichia coli isolates from poultry litter. Appl. Environ. Microbiol., 78: 5444-5447.

Prescott, J.F., Baggot, J.D. and Walker, R.D. 2000. Fluoroquinolones. In: Antimicrobial Therapy in Veterinary Medicine. Prescott J.F, J.D. Baggot and R.D. Walker, 3rd Edn., Iowa State University Press, Iowa, pp. 315-339.

Reyes-Herrera, I., Schneider, M.J., Blore, P.J. and Donoghue, D.J. 2011. The relationship between blood and muscle samples to monitor for residues of the antibiotic enrofloxacin in chickens. Poult. Sci., 90: 481-485.

San Martin, B., Cornejo, J., Iraguen, D., Hidalgo, H. and Anadon, A. 2007. Depletion study of enrofloxacin and its metabolite ciprofloxacin in edible tissues and feathers of white leghorn hens by liquid chromatography coupled with tandem mass spectrometry. J. Food Prot., 70: 1952-1957.

San Martin, B., Cornejo, J., Lapierre, L., Iraguen, D., Perez, F., Hidalgo, H. and Andre, F. 2010. Withdrawal time of four pharmaceutical formulations of enrofloxacin in poultry according to different maximum residues limits. J. Vet. Pharmacol. Ther., 33: 246-251.

Schneider, M.J. 2001. Multiresidue analysis of fluoroquinolone antibiotics in chicken tissue using automated microdialysisliquid chromatography. J. Chromatogr. Sci., 39: 351-356.

Sumano, L.H., Gutierrez, O.L. and Zamora, M.A. 2001. Bioequivalence of four preparations of enrofloxacin in poultry. J. Vet. Pharmacol. Ther., 24: 309-313.

Sumano, L.H. and Ocampo, C.L. 1995. Compositional analysis surveillance of eleven brands of enrofloxacin including Baytril R for veterinary use. J. Vet. Med., Series A, 42: 669673.

Sureshkumar, V. and Sarathchandra, G. 2018. A HPTLCFluorescent densitometry assay for simultaneous detection of enrofloxacin and ciprofloxacin in broiler chicken tissues. Food Anal. Methods, 11: 1076-1085.

Sureshkumar, V., Sarathchandra, G., Ramesh, J., Vairamuthu, S., Thejomoorthy, P. and Hariharan, P. 2012. The effect of enrofloxacin administration on haematological profile in broiler chicken - A safety pharmacology study. The Indian J. Field Veterin., 8: 20-24.

Vishnuraj, M.R., Kandeepan, G., Rao, K.H., Chand, S. and Kumbhar, V. 2016. Occurrence, public health hazards and detection methods of antibiotic residues in foods of animal origin: A comprehensive review. Cogent Food Agric., 2: 1-8.

Waghamare, R.N., Paturkar, A.M., Vaidya, V.M., Zende, R.J., Kumar, A. and Bedi, J.S. 2020. Screening of antimicrobial residues and confirmation of doxycycline in samples collected from chicken farms and processing units located around Mumbai, India. Indian J. Anim. Res., 54: 1415-1421. 